\title{
FAKTOR-FAKTOR YANG BERPENGARUH TERHADAP INDEKS PRESTASI SEMESTER (IPS) MAHASISWA S1 KEPERAWATAN UNIVERSITAS MUHAMMADIYAH GRESIK
}

\author{
Nourma Yunita ${ }^{1}$, Siti Mudlikah ${ }^{2}$. \\ Universitas Muhammadiyah Gresik \\ Nourta83@umg.ac.id
}

\begin{abstract}
Abstrak
Masa depan dan keunggulan bangsa ditentukan oleh keunggulan sumber daya manusia (SDM) dalam sektor pendidikan. Berdasarkan data dari Dirjen dikti tahun 2017 menunjukkan masih banyaknya mahasiswa yang putus kuliah dikarenakan kurangnya minat dan motivasi dari mahasiswa dan peran serta dari orang tua sehingga hal tersebut menjadi kendala sebagian besar mahasiswa tidak melanjutkan studi. Tujuan dari penelitian ini adalah untuk mengetahui faktor-faktor yang berpengaruh terhadap indeks prestasi sementara mahasiswa S1 Keperawatan fakultas Kesehatan Universitas Muhammadiyah Gresik

Jenis penelitian Analitik, desain penelitian observasional, dengan pendekatan waktu cross sectional. Besar sampel pada penelitian ini sebanyak 60 mahasiswa dengan variabel independen (motivasi, minat, gaya belajar, dan dukungan orang tua) dan variabel dependen (IPS) dengan menggunakan uji Rank spearman correlation untuk mengetahui hubungan dari masing-masing variabel independen dengan variabel dependen. Untuk mengetahui pengaruh secara bersamasama variabel independen terhadap variabel dependen menggunakan uji Regresi ordinal.

Hasil penelitian menunjukkan motivasi tinggi (75\%), minat tinggi $(71,2 \%)$, gaya belajar visual $(63,4 \%)$, dukungan baik dari orang tua $(73,1 \%)$ dan IP S dengan pujian $(88,5 \%)$. Kesimpulan analisis multivariat menunjukkan dukungan orang tua merupakan faktor yang paling dominan berpengaruh terhadap IPS dibandingkan faktor motivasi, minat, dan gaya belajar mahasiswa.
\end{abstract}

Katakunci: Motivasi, minat, gaya belajar, dukungan orang tua, IPS

The future and excellence nation determined by preeminence human resources in educational sector. Based on data of dirjen dikti year 2010 showed are still many students drop out of college because a lack interest and the motivations of students and the participation of parents so that it becomes constraint most students didn't continuiting studies. The aim of this research is to find out the factors influencing cumulative grade pint $S 1$ Nursing fakultas Kesehatan Universitas Muhammadiyah Gresik 2019.

The research of analytic, observational studies design, with the approach of the time cross sectional. Large sample on this research as many as 60 student with the independent variable (motivation, interest, learning style, and support of parents) and the dependent variable (IPS) by using test rank spearman correlation to know the relation of each independent variable with the dependent variable. To know the influence of jointly the independent variable against the dependent variable for use of regression ordinal test.

The results showed high motivation (75\%), high interest $(71.2 \%)$, visual learning style $(63,4 \%)$, good support from parents $(73,1 \%)$ and $\operatorname{GPC}(88,5 \%)$. Multivariate analysis showed support of parents is the most dominant factor affect IPS than factors motivation, interests, and learning styles of students.

Keywords: Motivation, interests, learning style, support parents, IPS.

\section{PENDAHULUAN}

Di era reformasi Ilmu Pengetahuan dan Tehnologi, perbaikan kegiatan belajar mengajar harus diupayakan secara maksimal agar mutu pendidikan meningkat. Hal ini dilakukan karena 
majunya pendidikan membawa implikasi meluas terhadap pemikiran manusia dalam berbagai bidang sehingga setiap generasi muda harus belajar banyak untuk menjadi manusia terdidik sesuai dengan tuntutan zaman (Mudyoharjo,2017). Sebagaimana tertuang dalam Undang-Undang Sistem Pendidikan Nasional bahwa pendidikan nasional berfungsi mengembangkan kemampuan dan membentuk watak serta peradaban bangsa yang bermartabat dalam rangka mencerdaskan kehidupan bangsa, yang bertujuan untuk berkembangnya potensi agar menjadi manusia yang beriman dan bertaqwa kepada Tuhan Yang Maha Esa, berakhlak mulia, sehat, berilmu, cakap, kreatif, mandiri, dan menjadi warga negara yang demokratis serta bertanggung jawab (Sisdiknas, 2014).

Data dari Dirjen dikti tahun 2018 menunjukkan masih banyaknya mahasiswa yang putus kuliah atau Drop out dengan jumlah 245.810 orang, diantaranya dikarenakan kurangnya minat dan motivasi dari mahasiswa tersebut untuk melanjutkan studi. Selain itu ada sebagian dari mahasiswa putus kuliah dikarenakan kurangnya biaya untuk melanjutkan pendidikan. Saat ini di jawa timur telah berdiri lebih dari 51 institusi pendidikan S1 Keperawant. Namun, perkembangan lulusan S1 Keperawant yang sedemikian pesat nyatanya belum mampu menjawab tantangan kebutuhan bidan yang kompeten, dengan cara melanjutkan jenjang pendidikan yang lebih tinggi. Sedangkan pendidikan S2 Keperawatan juga sudah banyak bermunculan. Berbagai penelitian menunjukan bahwa kualitas lulusan Keperawatan yang dihasilkan belum dapat memenuhi tuntutan penyediaan bidan yang berkualitas (KEMENDIKBUD, 2010).

Menurut ketua Pengurus Perawat Nasional Indonesia Prof. Dr. Nursalam, M.Nurs (Hons). menyatakan bahwa jumlah kenggotaan PPNI di Indonesia tahun 2017, dengan jumlah Anggota \pm 384.946 orang. Jumlah tersebut sangatlah sedikit sekali untuk mencetak generasi-generasi perawat selanjutnya. Berhasilnya suatu tujuan pendidikan tergantung pada bagaimana proses belajar mengajar yang dialami oleh siswa. Seorang pengajar dituntut untuk teliti dalam memilih dan menerapkan metode pengajaran yang sesuai dengan tujuan yang ingin dicapai. Menciptakan kegiatan belajar mengajar yang mampu menciptakan hasil belajar yang efektif merupakan tugas dan tanggung jawab pengajar (Slameto, 2015).

Belajar merupakan suatu bentuk pertumbuhan atau perubahan dalam diri seseorang yang dinyatakan dalam cara-cara bertingkah laku yang baru berkat pengalaman dan latihan (Oemar Hamalik, 2015). Aktivitas belajar tersebut bersifat kompleks karena merupakan suatu proses yang dipengaruhi oleh banyak faktor dan 
meliputi berbagai aspek baik yang bersumber dari dalam diri maupun dari luar diri manusia. Aktivitas belajar bagi setiap individu tidak selamanya berlangsung wajar, kadang dapat lancar, kadang-kadang tidak, kadang dapat cepat menangkap apa yang dipelajari, kadang terasa sulit. Kenyataan ini sering dijumpai pada setiap mahasiswa dalam kehidupan sehari-hari. Setiap individu tidaklah sama. Hal ini yang menyebabkan perbedaan tingkah laku belajar dikalangan mahasiswa (Ahmadi, 2017). Hasil belajar sama dengan prestasi belajar merupakan taraf kemampuan yang telah dicapai siswa setelah mengikuti proses belajar mengajar dalam waktu tertentu baik berupa perubahan tingkah laku, ketrampilan dan pengetahuan selanjutnya diukur dan dinilai yang kemudian diwujudkan dalam angka atau pernyataan (Slameto, 2015). Prestasi belajar merupakan nilai prestasi yang mencerminkan tingkat-tingkat mahasiswa sejauh mana telah dapat mencapai tujuan yang ditetapkan setiap mata kuliah (Arikunto, 2015). Upaya untuk meningkatkan prestasi belajar ini pun telah banyak dilakukan (Suryanti, Khikmiyah, Zawawi, \& Fauziyah, 2014)

Faktor - faktor yang mempengaruhi prestasi belajar di bagi menjadi dua yakni intern dan ekstern. Faktor Intern berasal dari dalam diri mahasiswa sendiri seperti motivasi belajar, minat, gaya belajar, kesehatan, intelegensi dan bakat. Faktor ekstern berasal dari dukungan orang tua, masyarakat, lingkungan sekitar, sekolah atau kampus, yaitu karena faktor dosen, metode pembelajaran, bahan bacaan, kurikulum, kondisi gedung dan alat pelajaran (Dalyono, 2010).

Tidak banyak mahasiswa yang menyadari kesulitan yang dialaminya, Tetapi tak dapat dipungkiri bahwa banyak mahasiswa yang mengalami kesulitan, bahkan kegagalan seperti tak lulus ujian atau mendapat angka yang buruk dalam ujian. Sebagian besar mahasiswa yang berulangkali mengalami kegagalan dalam studinya akan menimbulkan kejengkelan, kemarahan, kemalasan, kebosanan dan bahkan kebencian. Pada akhirnya mahasiswa terpaksa harus meninggalkan bangku kuliahnya dengan segala macam kerugian berupa gangguan mental, kerugian biaya dan kehancuran dalam seluruh hidupnya (Oemar Hamalik, 2015).

Upaya memperbaiki cara belajar sangat diperlukan untuk menghindari kegagalan dalam belajar. Upaya yang dapat dilakukan adalah dengan mengenal sedini mungkin jenis kesulitan belajar dan mencari sumber penyebab utama dan penyerta yang menimbulkan kesulitan 
belajar (Ahmadi dan Widodo S, 2014). Penataan dan pembinaan lembaga pendidikan yang bersifat strategik perlu disusun dan dilaksanakan. Pengembangan kurikulum yang mengacu pada kurikulum nasional, bentuk pengalaman belajar yang relevan dan pengembangan sumber daya pendidikan yang diperlukan serta pembinaan dan perlu pengembangan kemampuan/keterampilan merupakan langkah-langkah pembinaan lembaga pendidikan harus dilakukan. Berdasarkan latar belakang ini, maka peneliti tertarik untuk meneliti pengaruh dari faktor-faktor yang berpengaruh terhadap Indeks Prestasi Semester (IPS) pada mahasiswa S1 Keperawatan Universitas Muhammadiyah Gresik.

\subsection{Rumusan Masalah}

Dari latar belakang di atas maka dapat dirumuskan permasalahan yang merupakan fokus dalam penelitian ini :

“Apakah faktor-faktor yang berpengaruh terhadap Indeks Prestasi Semester (IPS) pada mahasiswa S1 Keperawatan Universitas Muhammadiyah Gresik ?"

\subsection{Tujuan Penelitian}

\subsubsection{Tujuan Umum}

Mengetahui faktor-faktor yang berpengaruh terhadap indeks prestasi Semester (IPS) pada mahasiswa S1 Keperawatan Universitas

\subsubsection{Tujuan Khusus}

Adapun tujuan khususnya adalah sebagai berikut :

1. Mengidentifikasi faktor yang berpengaruh terhadap Indeks Prestasi Semester (motivasi, minat, gaya belajar, dukungan orang tua)

2. Mengidentifikasi Indeks Prestasi Semester (IPS)

3. Mengetahui hubungan motivasi belajar dengan Indeks Prestasi Semester (IPS)

4. Mengetahui hubungan minat belajar dengan Indeks Prestasi Semester (IPS)

5. Mengetahui hubungan gaya belajar dengan Indeks Prestasi Semester (IPS)

6. Mengetahui hubungan dukungan orang tua dengan Indeks Prestasi Semester (IPS)

7. Menganalisis secara bersama-sama faktor yang berpengaruh terhadap Indeks Prestasi Semester (IPS)

\subsection{Manfaat Penelitian}

\subsubsection{Manfaat Praktis}

Dari hasil penelitian ini diharapkan dapat memberikan sumbangan bagi ilmu pengetahuan khususnya dalam hal pengembangan proses belajar, dan sebagai sarana pembanding bagi dunia ilmu pengetahuan dalam memperkaya informasi

Muhammadiyah Gresik . 
tentang proses belajar mengajar agar lebih efektif dan efisien.

\subsubsection{Manfaat Teoritis}

Dapat meningkatkan kualitas/mutu sumber daya manusia dan fasilitas dalam proses pendidikan agar nantinya mencetak tenaga-tenaga Kebidanan yang benar-benar professional. Serta dapat juga dijadikan sebagai sarana untuk menelaah sejauh mana ilmu pengetahuan yang telah peneliti pelajari, dengan kenyataan dalam praktek dan mempunyai pengetahuan dan pengalaman baru yang akan didapat selama melakukan penelitian ini.

\section{METODE}

Jenis penelitian ini adalah penelitian analitik dan desain penelitian Observasional. dan berdasarkan pendekatan waktu menggunakan Cross Sectional. Populasi dalam penelitian ini adalah seluruh mahasiswa S1 keperawatan di Universitas Muhammadiyah Gresik dengan jumlah 52 mahasiswa.

Dalam penelitian ini sampel yang digunakan adalah mahasiswa S1 keperawatan di Universitas Muhammadiyah Gresik dengan jumlah sebanyak 55 mahasiswa.

Cara pengumpulan data dengan cara wawancara, arsip nilai mahasiswa Fakultas kesehatan universitas
Muhammadiyah gresik dan mengisi lembar kuesioner

Analisis data dilakukan dengan menggunakan uji Spearman Rank Correlation dengan tingkat kepercayaan $95 \%(\alpha=0,05)$. Untuk mengetahui hubungan antara keempat variabel yaitu motivasi, minat, intelegensi dan minat yaitu menggunakan uji Spearman Rank Correlation.

\section{HASIL PENELITIAN}

Tabel 4.1 Distribusi frekuensi motivasi mahasiswa S1 Keperawatan terhadap Indeks Prestasi Sementara (IPS) di Universitas Muhammadiyah Gresik bulan Juli 2019.

\begin{tabular}{|l|c|c|}
\hline $\begin{array}{c}\text { Klasifikasi } \\
\text { Motivasi }\end{array}$ & Jumlah & $\begin{array}{c}\text { Persentase } \\
(\%)\end{array}$ \\
\hline Tinggi & 39 & 75 \\
\hline Sedang & 13 & 25 \\
\hline Rendah & 0 & 0 \\
\hline Total & 52 & 100 \\
\hline
\end{tabular}

Berdasarkan tabel 4.1 dapat diketahui bahwa motivasi mahasiswa S1 Keperawatan terhadap Indeks Prestasi Semester (IPS) lebih banyak yang termotivasi atau dengan kategori motivasi tinggi sebanyak 39 mahasiswa $(75 \%)$

Tabel 4.1 Distribusi frekuensi minat mahasiswa S1 Keperawatan terhadap Indeks Prestasi Sementara 
(IPS) di Universitas Muhammadiyah Gresik bulan Juli 2019

\begin{tabular}{|c|c|c|}
\hline $\begin{array}{c}\text { Klasifikasi } \\
\text { Minat }\end{array}$ & Jumlah & $\begin{array}{c}\text { Persentase } \\
(\%)\end{array}$ \\
\hline Tinggi & 37 & 71,2 \\
\hline Sedang & 14 & 26,9 \\
\hline Rendah & 1 & 1,9 \\
\hline Total & 52 & 100 \\
\hline
\end{tabular}

Berdasarkan tabel 4.2 dapat diketahui bahwa minat mahasiswa S 1 Keperawatan terhadap Indeks Prestasi Semester (IPS) lebih banyak yang memiliki minat dengan kategori tinggi sebanyak 37 mahasiswa $(71,2 \%)$.

Tabel 4.3 Distribusi frekuensi gaya belajar mahasiswa S1 Keperawatan terhadap Indeks Prestasi Sementara (IPS) di Universitas Muhammadiyah Gresik bulan Juli 2019

\begin{tabular}{|c|c|c|}
\hline $\begin{array}{c}\text { Klasifikasi } \\
\text { Gaya Belajar }\end{array}$ & Jumlah & $\begin{array}{c}\text { Persentase } \\
(\mathbf{\%})\end{array}$ \\
\hline Visual & 33 & 63,4 \\
\hline Auditori & 11 & 21,2 \\
\hline Kinestetik & 8 & 15,4 \\
\hline Total & 52 & 100 \\
\hline
\end{tabular}

Berdasarkan tabel 4.3 dapat diketahui bahwa gaya belajar mahasiswa S1 Keperawatan terhadap Indeks Prestasi Semester (IPS) lebih banyak dengan kategori Visual sebanyak 38 mahasiswa $(63,4 \%)$,
Tabel 4.4 Distribusi frekuensi dukungan orang tua mahasiswa S1 Keperawatan terhadap Indeks Prestasi Sementara (IPS) di Universitas Muhammadiyah Gresik bulan Juli 2019

\begin{tabular}{|c|c|c|}
\hline $\begin{array}{c}\text { Klasifikasi } \\
\text { Dukungan } \\
\text { Orang Tua }\end{array}$ & Jumlah & $\begin{array}{c}\text { Persentase } \\
(\%)\end{array}$ \\
\hline Baik & 38 & 73,1 \\
\hline Cukup & 14 & 26,9 \\
\hline Kurang & 0 & 0 \\
\hline Total & 52 & 100 \\
\hline
\end{tabular}

Berdasarkan tabel 4.4 dapat diketahui bahwa dukungan orang tua mahasiswa S1 Keperawatan terhadap Indeks Prestasi Semester (IPS) lebih banyak memiliki dukungan baik dari orang tua sebanyak 38 mahasiswa $(73,1 \%)$,

Tabel 4.5 : Distribusi frekuensi Indeks Prestasi Semester (IPS) mahasiswa S1 Keperawatan di Universitas Muhammadiyah Gresik bulan Juli 2019.

\begin{tabular}{|c|c|c|}
\hline $\begin{array}{c}\text { Klasifikasi } \\
\text { IPS }\end{array}$ & Jumlah & $\begin{array}{c}\text { Persentase } \\
(\%)\end{array}$ \\
\hline Dengan pujian & 46 & 88,5 \\
\hline $\begin{array}{c}\text { Sangat } \\
\text { Memuaskan }\end{array}$ & 6 & 11,5 \\
\hline Memuaskan & 0 & 0 \\
\hline Total & 52 & 100 \\
\hline
\end{tabular}

Berdasarkan tabel 4.5 dapat diketahui bahwa Indeks Prestasi Semester (IPS) mahasiswa S1 keperawatan lebih banyak yang 


\begin{tabular}{|l|c|c|c|c|c|c|c|c|}
\hline \multirow{4}{*}{ Minat } & \multicolumn{7}{|c|}{ IPS } & \multicolumn{2}{c|}{ Total } \\
\cline { 2 - 9 } & \multicolumn{2}{|c|}{ Dengan pujian } & $\begin{array}{c}\text { Sangat } \\
\text { memuaska } \\
\mathrm{n}\end{array}$ & \multicolumn{2}{c|}{ Memuaskan } & \multicolumn{2}{c|}{} \\
\cline { 2 - 10 } & $\mathrm{n}$ & $\%$ & $\mathrm{~N}$ & $\%$ & $\mathrm{n}$ & $\%$ & $\mathrm{n}$ & $\%$ \\
\hline Tinggi & 35 & 94,6 & 2 & 5,4 & 0 & 0 & 37 & 100 \\
\hline Sedang & 11 & 78,6 & 3 & 21,4 & 0 & 0 & 14 & 100 \\
\hline Rendah & 0 & 0 & 1 & 100 & 0 & 0 & 1 & 100 \\
\hline Total & 46 & 88,5 & 6 & 11,5 & 0 & 0 & 52 & 100 \\
\hline
\end{tabular}

memiliki IPK dengan kriteria dengan ujian dengan yakni sebanyak 46 mahasiswa $(88,5 \%)$.

Tabel 4.6: Tabulasi silang antara Indeks Prestasi Semester (IPS) dengan motivasi mahasiswa S1 Keperawatan di Universitas Muhammadiyah Gresik bulan Juli 2019

\begin{tabular}{|l|c|c|c|c|c|c|c|c|}
\hline \multirow{3}{*}{ Motivasi } & \multicolumn{9}{|c|}{ IPS } & \multicolumn{2}{|c|}{ Total } \\
\cline { 2 - 10 } & \multicolumn{2}{|c|}{$\begin{array}{c}\text { Dengan } \\
\text { pujian }\end{array}$} & \multicolumn{2}{c|}{$\begin{array}{c}\text { Sangat } \\
\text { memuaskan }\end{array}$} & \multicolumn{2}{c|}{ Memuaskan } & \multicolumn{2}{|c|}{} \\
\cline { 2 - 10 } & $\mathrm{n}$ & $\%$ & $\mathrm{n}$ & $\%$ & $\mathrm{n}$ & $\%$ & $\mathrm{n}$ & $\%$ \\
\hline Tinggi & 36 & 92,3 & 3 & 7,7 & 0 & 0 & 39 & 100 \\
\hline Sedang & 10 & 76,9 & 3 & 23,1 & 0 & 0 & 13 & 100 \\
\hline Rendah & 0 & 0 & 0 & 0 & 0 & 0 & 0 & 100 \\
\hline Total & 46 & 88,5 & 6 & 11,5 & 0 & 0 & 52 & 100 \\
\hline
\end{tabular}

Berdasarkan tabel 4.6 dapat diketahui bahwa mahasiswa yang memiliki IPS dengan pujian proporsi motivasi sedang (76,9\%) lebih Kecil dibandingkan dengan mahasiswa yang memiliki proporsi motivasi tinggi $(92,3 \%)$.

Tabel 4.7 : Tabulasi silang antara Indeks Prestasi Kumulatif (IPS) dengan minat mahasiswa S1 Keperawatan di Universitas
Muhammadiyah Gresik bulan Juli 2019

Berdasarkan tabel 4.7 dapat diketahui bahwa mahasiswa yang memiliki IPS dengan pujian proporsi minat tinggi (94,6\%) lebih besar dibandingkan dengan mahasiswa yang memiliki proporsi minat sedang $(78,6 \%)$.

Tabel 4.8 : Tabulasi silang Indeks antara Prestasi Semester (IPS) dengan gaya belajar mahasiswa S1 Keperawatan di Universitas Muhammadiyah Gresik bulan Juli 2019.

\begin{tabular}{|l|c|c|c|c|c|c|c|c|}
\hline \multirow{2}{*}{$\begin{array}{c}\text { Gaya } \\
\text { Belajar }\end{array}$} & \multicolumn{9}{|c|}{$\begin{array}{c}\text { IPS } \\
\text { pujian }\end{array}$} & \multicolumn{2}{|c|}{$\begin{array}{c}\text { Sangat } \\
\text { memuaskan }\end{array}$} & \multicolumn{2}{|c|}{ Memuaskan } & \multicolumn{2}{|c|}{ Total } \\
\cline { 2 - 9 } & $\mathrm{n}$ & $\%$ & $\mathrm{~N}$ & $\%$ & $\mathrm{n}$ & $\%$ & $\mathrm{n}$ & $\%$ \\
\hline Visual & 31 & 93,9 & 2 & 6,1 & 0 & 0 & 33 & 100 \\
\hline Auditori & 9 & 81,8 & 2 & 18,2 & 0 & 0 & 11 & 100 \\
\hline Kinestetik & 6 & 75 & 2 & 25 & 0 & 0 & 8 & 100 \\
\hline Total & 46 & 88,5 & 6 & 11,5 & 0 & 0 & 52 & 100 \\
\hline
\end{tabular}

Berdasarkan tabel 4.8 dapat diketahui bahwa mahasiswa yang memiliki IPS baik proporsi gaya belajar visual $(93,9 \%)$ lebih besar dibandingkan dengan mahasiswa yang memiliki gaya belajar auditori $(81,8 \%)$ dan mahasiswa yang memiliki proporsi gaya belajar kinestetik (75\%).

Tabel 4.9 : Tabulasi silang antara Indeks Prestasi Semester (IPS) 
dengan dukungan orang tua

mahasiswa S1 Keperawatan di

Universitas Muhammadiyah Gresik

bulan Juli 2019

\begin{tabular}{|c|c|c|c|c|c|c|c|c|}
\hline \multirow{2}{*}{$\begin{array}{c}\text { Dukungan } \\
\text { Orang Tua }\end{array}$} & \multicolumn{9}{|c|}{$\begin{array}{c}\text { Dengan } \\
\text { pujian }\end{array}$} & \multicolumn{2}{|c|}{$\begin{array}{c}\text { Sangat } \\
\text { memuaskan }\end{array}$} & \multicolumn{2}{|c|}{ Memuaskan } & \multicolumn{3}{|c|}{ Total } \\
\cline { 2 - 10 } & $\mathrm{n}$ & $\%$ & $\mathrm{n}$ & $\%$ & $\mathrm{n}$ & $\%$ & $\mathrm{n}$ & $\%$ \\
\cline { 2 - 10 } & 36 & 94,7 & 2 & 5,3 & 0 & 0 & 38 & 100 \\
\hline Baik & 10 & 71,4 & 4 & 28,6 & 0 & 0 & 14 & 100 \\
\hline Cukup & 0 & 0 & 0 & 0 & 0 & 0 & 0 & 100 \\
\hline Kurang & 46 & 88,5 & 6 & 11,5 & 0 & 0 & 52 & 100 \\
\hline Total & & & & & & & \\
\hline
\end{tabular}

menggunakan uji statistik Spearman Rank Correlation dengan tingkat kepercayaan 95\% $(\alpha=0,05)$ untuk mengetahui adanya hubungan yang signifikan antara variabel bebas (motivasi, minat,gaya belajar dan dukungan orang tua) dengan variabel terikat (indeks prestasi kumulatif) dan

Berdasarkan tabel 4.9 dapat diketahui bahwa mahasiswa yang memiliki IPK dengan pujian proporsi dukungan orang tua baik $(94,7 \%)$ lebih besar dibandingkan dengan mahasiswa yang memiliki proporsi dukungan orang tua cukup $(71,4 \%)$.

Tabel 4.10: Hubungan antara motivasi, minat, gaya belajar dan dukungan orang tua dengan IPS mahasiswa S1 Keperawatan di Universitas Muhammadiyah Gresik bulan Juli 2019.

\begin{tabular}{|c|c|c|c|c|c|c|}
\hline \multirow[b]{2}{*}{$\begin{array}{l}\mathrm{N} \\
\mathrm{o}\end{array}$} & \multicolumn{2}{|c|}{ Variabel } & \multirow[b]{2}{*}{$\begin{array}{c}\text { Uji } \\
\text { Statistik }\end{array}$} & \multirow{2}{*}{$\begin{array}{c}\text { Probabi } \\
\text { lity } \\
\text { Value } \\
\text { (P) }\end{array}$} & \multirow[b]{2}{*}{$\begin{array}{c}\text { Has } \\
\text { il }\end{array}$} & \multirow[b]{2}{*}{$\begin{array}{c}\text { Keteran } \\
\text { gan }\end{array}$} \\
\hline & $\begin{array}{c}\text { Indepen } \\
\text { den }\end{array}$ & $\begin{array}{l}\text { Depend } \\
\text { en }\end{array}$ & & & & \\
\hline 1. & Motivasi & IPS & $\begin{array}{c}\text { Rank } \\
\text { spearm } \\
\text { an } \\
\text { correlat } \\
\text { ion }\end{array}$ & .000 & $\begin{array}{c}\mathrm{p}< \\
\alpha\end{array}$ & $\begin{array}{c}\text { Karena } \\
\mathrm{p}<\alpha, \\
\text { maka } \\
\text { Ho di } \\
\text { Tolak }\end{array}$ \\
\hline 2. & Minat & IPS & $\begin{array}{c}\text { Rank } \\
\text { spearm } \\
\text { an } \\
\text { correlat } \\
\text { ion }\end{array}$ & .000 & $\begin{array}{c}\mathrm{p}< \\
\alpha\end{array}$ & $\begin{array}{c}\text { Karena } \\
\mathrm{p}<\alpha, \\
\text { maka } \\
\text { Ho di } \\
\text { Tolak }\end{array}$ \\
\hline 3. & $\begin{array}{c}\text { Gaya } \\
\text { Belajar }\end{array}$ & IPS & $\begin{array}{c}\text { Rank } \\
\text { spearm } \\
\text { an } \\
\text { correlat } \\
\text { ion }\end{array}$ & .000 & $\begin{array}{c}\mathrm{p}< \\
\alpha\end{array}$ & $\begin{array}{c}\text { Karena } \\
\mathrm{p}<\alpha, \\
\text { maka } \\
\text { Ho di } \\
\text { Tolak }\end{array}$ \\
\hline 4. & $\begin{array}{c}\text { Dukung } \\
\text { an }\end{array}$ & IPS & $\begin{array}{c}\text { Rank } \\
\text { spearm }\end{array}$ & .000 & $\begin{array}{c}\mathrm{p}< \\
\alpha\end{array}$ & $\begin{array}{l}\text { Karena } \\
\mathrm{p}<\alpha,\end{array}$ \\
\hline
\end{tabular}

diperoleh hasil $\mathrm{P}=0,000$ antara masing-masing variabel bebas (motivasi, minat, gaya belajar dan dukungan orang tua) dengan variabel terikat (IPS).

Tabel 4.11 : Pengaruh motivasi, minat, gaya belajar, dan dukungan orang tua terhadap IPS mahasiswa S1 Keperawatan di Universitas Muhammadiyah Gresik bulan Juli 2019.

\begin{tabular}{|c|c|c|c|c|c|c|}
\hline \multirow{2}{*}{ No } & \multicolumn{2}{|c|}{ Variabel } & \multirow[b]{2}{*}{$\begin{array}{c}\text { Uji } \\
\text { Statistik }\end{array}$} & \multirow{2}{*}{$\begin{array}{c}\text { Probab } \\
\text { ility } \\
\text { Value } \\
\text { (P) }\end{array}$} & \multirow[b]{2}{*}{ Hasil } & \multirow[b]{2}{*}{ Keterangan } \\
\hline & Independen & $\begin{array}{c}\text { Depen } \\
\text { den }\end{array}$ & & & & \\
\hline 1. & Motivasi & IPS & $\begin{array}{l}\text { Regresi } \\
\text { Ordinal }\end{array}$ & .038 & $\mathrm{p}<\alpha$ & $\begin{array}{c}\text { Karena } \mathrm{p}< \\
\alpha, \text { maka Ho } \\
\text { di Tolak }\end{array}$ \\
\hline 2. & Minat & IPS & $\begin{array}{l}\text { Regresi } \\
\text { Ordinal }\end{array}$ & .008 & $\mathrm{p}<\alpha$ & $\begin{array}{c}\text { Karena } p< \\
\alpha, \text { maka Ho } \\
\text { di Tolak }\end{array}$ \\
\hline 3. & $\begin{array}{c}\text { Gaya } \\
\text { Belajar }\end{array}$ & IPS & $\begin{array}{l}\text { Regresi } \\
\text { Ordinal }\end{array}$ & .041 & $\mathrm{p}<\alpha$ & $\begin{array}{c}\text { Karena } \mathrm{p}< \\
\alpha, \text { maka Ho } \\
\text { di Tolak }\end{array}$ \\
\hline 4. & $\begin{array}{l}\text { Dukungan } \\
\text { Orang Tua }\end{array}$ & IPS & $\begin{array}{l}\text { Regresi } \\
\text { Ordinal }\end{array}$ & .000 & $\mathrm{p}<\alpha$ & $\begin{array}{c}\text { Karena } p< \\
\alpha, \text { maka Ho } \\
\text { di Tolak }\end{array}$ \\
\hline
\end{tabular}

Setelah dilakukan uji statistik Regresi Ordinal dengan memasukkan variabel independen (motivasi, minat, gaya belajar dan dukungan orang tua) 
secara bersama-sama melalui beberapa kali analisis multivariat dengan mencari nilai signifikansi $(p)$ terkecil $P$ $\leq$ 0,05 maka diketahui hasil analisis variabel yang lebih dominan berpengaruh terhadap indeks prestasi kumulatif adalah variabel dukungan orang tua mahasiswa dengan nilai $\mathrm{P}=$ 0.000 .

\section{PEMBAHASAN}

A. Motivasi mahasiswa S1 Keperawatan

Berdasarkan tabel 4.1 dapat diketahui bahwa motivasi mahasiswa S1 Keperawatan di Universitas Muhammadiyah Gresik.

Terhadap Indeks Prestasi Kumulatif (IPS) sebagian besar memiliki motivasi yang tinggi sebanyak 39 mahasiswa (75\%).

Pada hasil tersebut menunjukkan bahwa sebagian besar sebanyak 75\% mahasiswa S1 Keperawatar d: Universitas Muhammadiyah Gresık memiliki motivasi yang tinggi. Hal ini sesuai dengan kenyataan yang diharapkan dengan memiliki motivasi yang tinggi dalam belajar maka hasil yang didapat di harapkan mencapai nilai yang memuaskan.

Apalagi untuk mata pelajaran yang didalamnya membutuhkan suatu ketelitian dan kesabaran dalam mempelajarinya, sehingga membutuhkan motivasi yang kuat guna memberikan semangat belajar, dengan semangat belajar yang tinggi pencapaian prestasi belajar akan semakin mudah

B. Minat mahasiswa S1 Keperawatan

Berdasarkan tabel 4.2 dapat diketahui bahwa minat mahasiswa S1 Keperawatan di Universitas Muhammadiyah Gresik terhadap Indeks Prestasi Sementara (IPS) lebih banyak yang memiliki minat dengan kategori tinggi sebanyak 37 mahasiswa $(71,2 \%)$.

Pada hasil penelitian ini menunjukkan bahwa sebagian besar sebanyak 71,2\% mahasiswa S1 Keperawatan di Universitas Muhammadiyah Gresik memiliki minat yang tinggi dengan memiliki minat belajar yang tinggi maka hasil yang didapatkan akan sesuai dengan keinginan yang diharapkan.

Mahasiswa yang berminat terhadap kegiatan belajar akan berusaha lebih keras dibandingkan mahasiswa yang kurang minat. Minat dapat timbul karena adanya daya tarik dari luar dan juga datang dari sanubari. Timbulnya minat belajar disebabkan beberapa hal, antara lain karena keinginan yang kuat 
untuk menaikkan martabat atau memperoleh pekerjaan yang baik serta ingin hidup senang atau bahagia.

C. Gaya belajar mahasiswa S1 Keperawatan

Berdasarkan tabel 4.3 dapat diketahui bahwa gaya belajar mahasiswa S1 Keperawatan di Universitas Muhammadiyah Gresik terhadap Indeks Prestasi Semester (IPS) lebih banyak dengan kategori Visual sebanyak 33 mahasiswa $(63,4 \%)$.

Pada hasil tersebut menunjukkan bahwa sebanyak $63,4 \%$ gaya belajar mahasiswa $\mathrm{S} 1$ Keperawatan di Universitas Muhammadiyah Gresik adalah gaya belajar visual. Karena pada umumnya gaya visual ini memang merupakan gaya belajar yang paling banyak dimiliki mahasiswa. Dalam kenyataannya memang gaya belajar visual ini yang banyak diterapkan selama melakukan proses pembelajaran yakni mahasiswa lebih banyak melakukan pencatatan, membaca buku sendiri saat mengerjakan tugas, dan suka berdiskusi dengan temen-temannya.

Heinich (2009) Individu yang memiliki gaya belajar visual akan efektif melakukan proses belajar melalui kegiatan membaca, menggambar, dan fotografi. Bentuk tugas yang sesuai untuk siswa yang memiliki gaya belajar visual ini adalah pengamatan atau observasional. Belajar dengan cara visual itu lebih menguatkan daya ingat anak dan lebih tertanam pada anak tersebut. Gaya belajar Visual Learner adalah gaya belajar yang lebih banyak memanfaatkan "penglihatan" yang dimiliki oleh individu.

D. Dukungan orang tua mahasiswa S1 Keperawatan

Berdasarkan tabel 4.4 dapat diketahui bahwa dukungan orang tua mahasiswa S1 Keperawatan di Universitas Muhammadiyah Gresik terhadap Indeks Prestasi Semester (IPS) lebih banyak memiliki lukungan baik dari orang tua sebanyak 38 mahasiswa $(73,1 \%)$.

Dari hasil penelitian tersebut menunjukkan sebagian besar mahasiswa mendapatkan dukungan yang baik dari orang tua mereka dalam menjalani studi. Dukungan orang tua mempunyai peranan sangat penting dalam keberhasilan mahasiswa untuk mencapai nilai yang memuaskan karena orang tua tidak hanya memberikan dukungan secara materi tetapi dukungan 
secara moral akan sangat berpengaruh terhadap keberhasilan mahasiswa. Potensi seorang anak itu akan dapat berkembang dengan baik apabila mendapat bimbingan dan dukungan serta pengawasan dari orang tuanya dalam pendidikan informalnya dan selalu terpenuhinya semua kebutuhan belajar akan lebih mudah dalam meraih prestasi dibandingkan dengan siswa yang tidak pernah mendapat perhatian, bimbingan dan dukungan dari orang tuanya.

E. Indeks Prestasi Kumulatif Mahasiawa S1 Keperawatan

Berdasarkan tabel 4.5 dapat diketahui bahwa Indeks Prestasi Semester (IPS) mahasiswa S1 Keperawatan di Universitas Muhammadiyah Gresik lphih banyak yang memiliki IPS dengaı kriteria dengan pujian yakni sebanyak 46 mahasiswa $(88,5 \%)$.

Pada hasil penelitian tersebut menunjukkan bahwa sebagian besar mahasiswa S1 Keperawatan di Universitas Muhammadiyah Gresik 88,5\% memiliki indeks prestasi kumulatif dengan kategori baik. Hal ini juga didukung dengan motivasi dan minat yang tinggi dari mahasiswa serta peran dari dukungan orang tua dan institusi terkait yang mendukung proses belajar mengajar sehingga menghasilkan prestasi belajar sebaik mungkin sesuai dengan usaha belajar yang dilakukan mahasiswa S1 Keperawatan di Universitas Muhammadiyah Gresik.

F. Hubungan motivasi dengan indeks prestasi Semester

Berdasarkan tabel 4.6 dapat diketahui bahwa mahasiswa yang memiliki IPS dengan pujian proporsi motivasi sedang $(92,3 \%)$ - Hasil diatas menunjukkan sebagian besar mahasiswa sebanyak 92,3\% yang memiliki IPS dengan pujian juga memiliki motivasi belajar yang sedang. Hal ini disebabkan ada pengaruh faktor lain selain motivasi yang mendukung sebagian besar mahasiswa S1 Keperawatan memiliki IPS dengan pujian. Jadi meskipun motivasi yang dimiliki dalam kategori sedang sebagian besar mahasiswa memiliki IPS dengan pujian. Hasil uji statistik menggunakan uji Spearman Rank correlation diperoleh hasil $\mathrm{P}=$ 0.000 , sehingga $\mathrm{P}<\alpha$ yang menunjukkan bahwa Ho ditolak dan 
$\mathrm{H}^{1}$ diterima yang artinya menunjukkan adanya hubungan yang signifikan antara motivasi dengan indeks prestasi mahasiswa S1 Keperawatan di Universitas Muhammadiyah Gresik

Motivasi mempunyai tiga komponen utama yaitu kebutuhan, dorongan dan tujuan. Kebutuhan terjadi bila individu merasa ada ketidak seimbangangan antara apa yang mereka miliki dengan apa yang mereka harapkan. Dorongan merupakan kekuatan mental untuk melakukan kegiatan dalam rangka memenuhi harapan. Dorongan merupakan kekuatan mental yang berorientasi pada pemenuhan harapan atau pencapaian tujuan. Dorongan yang berorientasi pada tujuan tersebut merupakan inti dari pada motivasi (Dimyati, dkk, 2015). Apalagi untuk mata pelajaran yang didalamnya membutuhkan suatu ketelitian dan kesabaran dalam mempelajarinya, sehingga membutuhkan motivasi yang kuat guna memberikan semangat belajar, dengan semangat belajar yang tinggi pencapaian prestasi belajar akan semakin mudah (Dalyono, 2010).
G. Hubungan minat dengan indeks prestasi semester

Berdasarkan tabel 4.7 dapat diketahui bahwa mahasiswa yang memiliki IPS dengan pujian proporsi minat tinggi $(94,6 \%)$. Hasil uji statistik menggunakan uji Spearman Rank correlation diperoleh hasil $\mathrm{P}=0.000$, sehingga $\mathrm{P}<\alpha$ yang menunjukkan bahwa Ho ditolak dan $\mathrm{H}^{1}$ diterima yang artinya menunjukkan adanya hubungan yang signifikan antara minat dengan indeks prestasi mahasiswa S1 Keperawatan di Universitas Muhammadiyah Gresik

Hasil diatas menunjukkan bahwa mahasiswa dengan minat yang tinggi dalam belajar idealnya akan mendapatkan nilai yang baik. Hal ini sesuai dengan penelitian diatas bahwa sebagian besar mahasiswa dengan minat belajar yang tinggi memiliki IPS dengan pujian sesuai dengan prosentase (94,6\%).

Jadi untuk melihat reaksi dari gejala psikis tersebut dapat dipastikan dari sikap, prilaku, atau motivasi yang dimiliki seseorang dalam melakukan aktifitas belajar. Minat juga berperan sangat penting 
Nourma Yunita, Faktor-faktro yang berpengaruh...

dalam kehidupan peserta didik dan mempunyai dampak yang besar terhadap sikap dan perilaku. Mahasiswa yang berminat terhadap kegiatan belajar akan berusaha lebih keras dibandingkan mahasiswa yang kurang minat. minat dapat timbul karena adanya daya tarik dari luar dan juga datang dari sanubari. Timbulnya minat belajar disebabkan beberapa hal, antara lain karena keinginan yang kuat untuk menaikkan martabat atau memperoleh pekerjaan yang baik serta ingin hidup senang atau bahagia. Dengan memiliki minat belajar, peserta didik lebih memperkuat ingatan tentang pelajaran yang diberikan oleh pendidik. Sehingga tidak sulit bagi peserta didik dalam mengerjakan soal atau menjawab pertanyaan. $\mathrm{Un}^{1}$ tersebut akan menghasilkan nılaı yang bagus dan meningkatkan prestasi peserta didik.

H. Hubungan gaya belajar dengan indeks prestasi semester

Berdasarkan tabel 4.8 dapat diketahui bahwa mahasiswa yang memiliki IPS dengan pujian proporsi gaya belajar visual $(93,9$ \%) Hasil uji statistik menggunakan uji Spearman Rank correlation diperoleh hasil $\mathrm{P}=0.000$, sehingga $\mathrm{P}<\alpha$ yang menunjukkan bahwa Ho ditolak dan $\mathrm{H}^{1}$ diterima yang artinya menunjukkan adanya hubungan yang signifikan antara gaya belajar dengan indeks prestasi mahasiswa S1 Keperawatan di Universitas Muhammadiyah Gresik. Hasil penelitian diatas menunjukkan sebagian besar mahasiswa yang memiliki IPS dengan pujian memiliki gaya belajar visual sebanyak (93,9\%). Hal ini menunjukkan bahwa gaya belajar tersebut sesuai dengan metode yang diberikan selama proses belajar mengajar yang menitik beratkan pada "Student centre learning" dan metode ini cukup memberikan hasil yang positif terhadap gaya belajar mahasiswa di Universitas Muhammadiyah Gresik.

Heinich (2009) Gaya belajar atau Learning styles adalah suatu cara tentang bagaimana seorang individu melakukan persepsi, berinteraksi, dan merespons secara emosional terhadap lingkungan belajar. Individu yang memiliki gaya belajar visual akan efektif melakukan proses belajar melalui kegiatan membaca, menggambar, 
dan fotografi. Bentuk tugas yang sesuai untuk siswa yang memiliki gaya belajar visual ini adalah pengamatan atau observasional. Gaya belajar dengan visual merupakan gaya belajar anak yang dilakukan dengan sendirinya, misalnya anak belajar dengan lebih banyak mencatat dan membaca buku sendiri dan berdiskusi dengan teman-temannya. Belajar dengan cara visual itu lebih menguatkan daya ingat anak dan lebih tertanam pada anak tersebut. Gaya belajar Visual Learner adalah gaya belajar yang lebih banyak memanfaatkan "penglihatan" yang dimiliki oleh individu.

I. Hubungan dukungan orang tua terhadap indeks prestasi semester

Berdasarkan tabel 4.9 dapat diketahui bahwa mahasiswa yang memiliki IPS baik proporsi dukungan orang tua baik $(94,7 \%)$. Hasil uji statistik menggunakan uji Spearman Rank correlation diperoleh hasil $\mathrm{P}=0.000$, sehingga $\mathrm{P}<\alpha$ yang menunjukkan bahwa Ho ditolak dan $\mathrm{H}^{1}$ diterima yang artinya menunjukkan adanya hubungan yang signifikan antara dukungan orang tua dengan indeks prestasi mahasiswa S1 keperawatan Universitas Muhammadiyah Gresik. Hasil diatas menunjukkan mahasiswa yang memiliki dukungan yang baik dari orang tua akan menghasilkan nilai yang baik pula dan ini dibuktikan dari hasil penelitian yang sebagian besar mahasiswa S1 keperawatan sebanyak $\quad(94,7 \% \quad)$ memiliki dukungan baik dari orang tua dan mendapatkan prestasi belajar dengan pujian.

Hasbullah (2014) menyatakan Orang tua adalah orang yang pertama dan utama yang bertanggung jawab terhadap kelangsungan hidup dan pendidikan anaknya. Oleh karena itu, sebagai orang tua harus dapat membantu dan mendukung terhadap segala usaha yang dilakukan oleh anaknya serta dapat memberikan pendidikan informal guna membantu pertumbuhan dan perkembangan anak tersebut serta untuk mengikuti atau melanjutkan pendidikan pada program pendidikan formal di sekolah.Dukungan orang tua meliputi dukungan moral yang berupa perhatian. Perhatian dari orang tua merupakan harapan 
semua anak di masa pertumbuhan dan perkembangannya.

J. Faktor motivasi, minat, gaya belajar, dukungan orang tua yang berpengaruh terhadap indeks prestasi semester.

Setelah dilakukan perhitungan menggunakan uji statistik Spearman Rank Correlation dengan tingkat kepercayaan 95\% $(\alpha=0,05)$ untuk mengetahui adanya hubungan yang signifikan antara variabel bebas (motivasi, minat, gaya belajar dan dukungan orang tua) dengan variabel terikat (indeks prestasi kumulatif) dan diperoleh hasil $\mathrm{P}=$ 0,000 antara masing-masing variabel bebas (motivasi, minat, gaya belajar dan dukungan orang tua) dengan variabel terikat (IPS). Hasil ini menunjukkan bahwa ri ditolak dan $\mathrm{H}^{1}$ diterima yang artinya menunjukkan adanya hubungan yang signifikan antara motivasi, minat, gaya belajar, dan dukungan orang tua terhadap indeks prestasi mahasiswa $\mathrm{S} 1$ keperawataan Universitas Muhammadiyah Gresik.

Kemudian untuk mengetahui pengaruh dari masing-masing variabel dilakukan uji statistik Regresi Ordinal dengan memasukkan variabel independen (motivasi, minat, gaya belajar dan dukungan orang tua) secara bersama-sama melalui beberapa kali analisis multivariat dengan mencari nilai signifikansi terkecil $\mathrm{P} \leq 0,05$ maka diketahui hasil analisis variabel yang lebih dominan berpengaruh terhadap indeks prestasi kumulatif adalah variabel dukungan orang tua mahasiswa dengan nilai $\mathrm{P}=0.000$. hasil ini menunjukkan adanya pengaruh yang lebih dominan antara dukungan orang tua mahasiswa terhadap indeks prestasi kumulatif mahasiswa Universitas Muhammadiyah Gresik.

Hal tersebut sesuai dengan teori yang dikemukakan oleh Hasbullah ( 2014) yang menyatakan Orang tua adalah orang yang pertama dan utama yang bertanggung jawab terhadap kelangsungan hidup dan pendidikan anaknya. Mengingat tanggung jawab pendidikan anak ditanggung oleh keluarga dalam pendidikan informalnya dan ditanggung oleh sekolah dalam pendidikan formal, maka orang tua harus berperan dalam menanamkan sikap dan nilai hidup, pengembangan bakat dan minat serta pembinaan bakat dan kepribadian. Pada dasarnya 
dukungan orang tua terhadap pendidikan anaknya menyangkut dua hal pokok yaitu dukungan moral dan dukungan material.

\section{PENUTUP}

Ada empat faktor yang berpengaruh terhadap indeks prestasi semester (IPS) mahasiswa S1 keperawatan universitas muhammadiyah gresik di antaranya motivasi, minat, gaya belajar, dukungan orang tua.

Dari empat faktor yang berpengaruh motivasi tinggi yang menduduki tempat pertama yang berpengaruh terhadap Indeks prestasi Sementara, sedangkan faktor ke dua yang berpengaruh terhadap Indeks prestasi Sementara adalah dukungan orang tua yang baik.

Kedua faktor tersebut sangat penting untuk mendapatkan indek prestasi sementara . karena berkat motivasi tinggi dan dukungan orang tua yang baik akan berpengaruh terhadap hasil nilai indeks prestasi sementara mahasiswa.

\section{SIMPULAN}

1. Mahasiswa S1 keperawatan Sebagian besar yaitu sebanyak (75 \%) memiliki motivasi tinggi, memiliki minat tinggi $(71,2 \%)$, memiliki gaya belajar visual $(63,4 \%)$, dan memiliki dukungan orang tua yang baik $(73,1$ $\%)$

2. Mahasiswa S1 keperawatan Sebagian besar $(88,5 \%)$ Sebagian besar memiliki indeks prestasi semestara dengan pujian

3. Mahasiswa S1 keperawatan Sebagian besar (92,3\%) memiliki IPS dengan pujian memiliki motivasi Tinggi.

4. Mahasiswa S1 keperawatan Sebagian besar (94,6 \%) memiliki IPS dengan pujian memiliki minat

5. Mahasiswa S1 keperawatan Sebagian besar (93,9\%) memiliki IPS dengan pujian memiliki gaya belajar visual.

6. Mahasiswa S1 keperawatan Sebagian besar $(94,7 \%)$ memiliki IPS dengan ujian memiliki dukungan yang baik dari orang tua

7. Hasil analisis secara bersama-sama menggunakan uji Regresi Ordinal menunjukkan faktor dukungan keluarga yang lebih dominan berpengaruh terhadap indeks prestasi kumulatif mahasiswa S1 keperawataan Universitas Muhammadiyah Gresik.

\section{SARAN}

\section{Bagi Institusi Pendidikan}

Diharapkan agar penelitian ini dapat digunakan sebagai asuhan dan bahan penelitian selanjutnya, serta 
dapat digunakan sebagai bahan bacaan. penelitian ini juga dapat dijadikan tambahan referensi di perpustakaan dan menambah pengetahuan tentang faktor-faktor yang berpengaruh terhadap indeks prestasi kumulatif bagi mahasiswa lain.

\section{Bagi Pengajar}

Bagi pengajar agar dapat memilih metode-metode pembelajaran yang yang tepat agar dapat memotivasi dan menumbuhkan minat mahasiswa dalam menjalani studi sehingga mahasiswa dapat memperoleh hasil belajar sebaik mungkin dan untuk mem 17 tercapainya tujuan pembelajaran bagi mahasiswa.

\section{Bagi Mahasiswa}

Diharapkan untuk lebih meningkatkan pengetahuan dan wawasan salah satunya dengan sering update informasi terbaru seputar pendidikan khususnya dibidang kesehatan baik melalui media cetak dengan membaca referensi di perpustakaan maupun menggunakan media sosial.

\section{Bagi Peneliti Selanjutnya}

Dalam melakukan penelitian sebaiknya melakukan penelitian dengan waktu yang cukup sehingga hasil penelitian yang diperoleh lebih akurat, dan perlu diadakan penelitian lebih lanjut dengan jumlah sampel yang lebih banyak dan dengan menggunakan metode yang lebih tepat dalam upaya mengetahui faktorfaktor apa saja yang lebih berpengaruh terhadap indeks prestasi semester (IPS). Serta perlu ditingkatkan lagi dukungan untuk mahasiswa karena dukungan orang tua pada penelitian ini besar pengaruhnya untuk mahasiswa dalam memperoleh prestasi khususnya dukungan dari orang tua agar mahasiswa lebih giat lagi dalam belajar dan menghasilkan prestasi yang baik.

\section{Referensi}

Ahmadi dan Widodo Supriyono. 2014. Psikologi Belajar. Jakarta: PT. Rineka Cipta.

Arikunto. 2015. Prosedur Penelitian Suatu Pendekatan Praktik, Jakarta: Rineka Cipta

Dalyono. 2010. Psikologi Pendidikan. PT Rineka Cipta.

Munib, Achmad, dkk. 2011. Pengantar Ilmu Pendidikan. Semarang: Universitas Negeri Semarang Press.

Oemar, Hamalik. (2015). Kurikulum dan Pembelajaran. Jakarta: Bumi Aksara.

Slameto. (2015). Belajar dan faktorfaktor yang mempengaruhinya. 
Cetakan Keenam. Jakarta: PT

Rineka Cipta.

Slameto, S. (2015). Pembelajaran

Berbasis Riset Mewujudkan

Pembelajaran Yang Inspiratif.

Satya Widya, 31(2), 102-112.

Sudjana, Nana. (2011). Penilaian Hasil

Proses Belajar Mengajar.

Bandung: PT Remaja Rosdakarya.

Sudjana, Nana. (2013). Dasar-dasar

Proses Belajar Mengajar

Bandung: Sinar Baru algesindo

Suryanti, S., Khikmiyah, F., Zawawi,

I., \& Fauziyah, S. (2014).

Peningkatan Penguasaan Konsep

Matriks Melalui Model

Pembelajaran Kooperatif Tipe

Two Stay Two Stray (Tsts).

DIDAKTIKA: Jurnal Pemikiran

Pendidikan, 21(1), 14-27. 